\title{
Cell-to-cell transmission of lymphocytic choriomeningitis virus MX strain during persistent infection and its influence on cell migration
}

\author{
M. LABUDOVÁ ${ }^{*}$, F. ČIAMPOR ${ }^{1}$, S. PASTOREKOVÁ ${ }^{1}$, J. PASTOREK ${ }^{1,2}$ \\ ${ }^{1}$ Institute of Virology, Biomedicine Center Slovak Academy of Sciences, Dúbravská cesta 9, 84505 Bratislava, Slovak Republic; \\ ${ }^{2}$ Department of Chemistry, Faculty of Natural Sciences, University of Ss. Cyril and Methodius, Trnava, Slovak Republic
}

Received June 7, 2018; accepted October 8, 2018

\begin{abstract}
Summary. - Lymphocytic choriomeningitis virus (LCMV) can establish in its host a persistent infection, without any prominent symptoms. Even during this infection, when the infectious virions are not released, the virus still disseminates effectively. A very effective and fast way of infection of neighboring cells utilized by many viruses is cell-to-cell transmission. Viruses use different ways of cell-to-cell spread through the extracellular space or by intracellular means through different protrusions. We have found that LCMV strain MX may use three different types of cell-to-cell transport. Firstly, similar to vaccinia virus, it can use actin to propel the virus towards the neighboring cell. Secondly, virus can travel through the intracellular space inside the tunneling nanotubes, that connect the cells even at longer distances and thirdly, the virus may travel on the surface of the membrane of different protrusions connecting two cells. We have also proved that the cells infected by MX strain of LCMV migrate faster than the uninfected cells or cells infected with a different LCMV strain. In accordance with faster migration, the infected cells form more lamellipodia with high expression of keratin 1. In this work, we have introduced three types of cell-to-cell transmission utilized by strain MX of LCMV and showed that even if the cells are not in tight connection, the virus forces them to migrate faster to join the nearest cell. As we show in this work, the virus may use more than one strategy to move to another cell, while each strategy can substitute another. These ways of transmission are very fast and effective and may have a serious impact on the host. Moreover, targeting the cell-to-cell spread, by inhibiting for instance GTPase dynamin, could be an effective way of virus elimination.
\end{abstract}

Keywords: lymphocytic choriomeningitis virus; transmission; migration; keratin 1; nucleoprotein

\section{Introduction}

Lymphocytic choriomeningitis virus (LCMV) belongs to the family Arenaviridae, a group of single stranded RNA viruses. Four viral proteins are encoded by four genes. Glycoprotein precursor (GPC), which is cleaved after translation into two glycoproteins, a peripheral protein GP1 and a transmembrane protein GP2 (Southern et al., 1987; Wright et al., 1990), nucleoprotein (NP), the most abundant viral protein,

*Corresponding author: E-mail: virulama@savba.sk; phone: +4212-59302439.

Abbreviations: $\mathrm{FA}=$ focal adhesion; $\mathrm{GP}=$ glycoprotein; $\mathrm{KF}=$ keratin filament; KFP = keratin filament precursor; K1 = keratin 1; LCMV = lymphocytic choriomeningitis virus; $\mathrm{NP}$ = nucleoprotein; $\mathrm{TNT}=$ tunneling nanotubes which encapsidates the RNA in nucleosome like structures and together with RNA dependent RNA polymerase (L protein) forms ribonucleoprotein, a minimal infectious unit (Southern et al., 1987; Salvato and Shimomaye, 1989). The last viral protein, Z-protein is a structural protein, which forms matrix of the virus with few regulatory functions and a ring finger structure (Salvato and Shimomaye, 1989). During replication, the virus utilizes an unusual two stage replication strategy called ambisense replication (Southern, 1996).

The LCM virus naturally persists in the common house mice (Mus musculus) and it circulates in its population. Humans may be infected by inhalation of aerosols from excretes in the nature or more commonly, during cleaning of the cellars, attics or sheds inhabited by mice (Jahrling and Peters, 1992; Peters et al., 1996). Infections from pet hamsters also occur (Jahrling and Peters, 1992; Peters et al., 1996). 
Several cases of infection during transplantation have been reported. Infections occurred after the transplantation of the organ from an infected person with no clinical symptoms. This may cause very serious complications and even death of the immunosuppressed recipient patient (MMWR-Dispatch, 2005; Fischer et al., 2006; Barry et al., 2008).

LCMV causes mainly persistent infections, which are characterized by very high expression of the viral NP and loss of GP (Buchmeier et al., 1980; Meyer and Southern, 1997). The unusual replication strategy facilitates establishment of virus persistence, which can be sustained by virus ribonucleoprotein composed of NP, RNA genome and $\mathrm{L}$ polymerase in the absence of mature virion production caused by lack or limited expression of glycoproteins (Van Der Zeijst et al., 1983). LCMV is not able to produce infectious virion particles during persistent infection, but defective interfering particles may occur (Popescu et al., 1976). Since there is no production of infectious particles, virus needs to establish a different way of transmission. Such transmission may be established by the use of cell-to-cell contacts, which is a common way of transmission for many viruses. Moreover, it appears to be more effective than the usual infection by virus-receptor interaction. By this way of transmission, the virus escapes the immune system and virus neutralizing antibodies, and the transmission is much faster since it doesn't always require the virus-receptor interaction (Zhong et al., 2013).

Previously we have identified that viral NP interacts with keratin $1(\mathrm{~K} 1)$, which is an intermediate filament directly connected with desmosomes (Labudova et al., 2009). K1 may act as a carrier, along which the viral ribonucleoprotein travels to the desmosomes, a tight cellular junction. The virus is thus carried to a place with tight connection to the neighboring cell where it can be transported to the target cell. The means of transport to the neighboring cell is still not certain, and here we describe three possible ways of cell-to-cell transport of persistent strain MX of LCMV. We have proved that cells infected by LCMV persistent strain MX migrate faster than uninfected cells and enable faster dissemination of the virus.

\section{Materials and Methods}

Viruses and cells. Lymphocytic choriomeningitis virus strain MX was continuously propagated in persistently infected cervical carcinoma cell line HeLa (designated as HeLa-MX, (Pastorekova et al., 1992; Reiserová et al., 1999)). The infection was established using a cell-free extract from MaTu cells prepared by the procedure of Van der Zeijst et al. (1983) (Reiserová et al., 1999). HeLa cells were infected by the strain ARM at MOI $=0.1$ for $90 \mathrm{~min}$. Noninfected HeLa cells cultured in parallel were used as a control. The cells were grown in DMEM medium containing stable $2 \mathrm{mmol} / \mathrm{l}$
L-glutamine, supplemented with 10\% fetal bovine serum (Lonza, Belgium) and $160 \mu \mathrm{g} / \mathrm{ml}$ gentamicin (Lek, Slovenia) at humidified atmosphere at $37^{\circ} \mathrm{C}$ in the presence of $5 \% \mathrm{CO}_{2}$. The cultures were maintained at high cell density to allow for easier virus transmission via cell-to-cell contacts.

Antibodies. Primary antibodies: We have used undiluted hybridoma medium of M87, a mouse monoclonal antibody specific for nucleoprotein of LCMV strain MX (Pastorekova et al., 1992; Reiserová et al., 1999). Anti-cytokeratin 1 (N-20) antibody that recognizes keratin 1 diluted 1:200 (Santa Cruz, USA). Phalloidin AF594 is a high-affinity F-actin probe (Thermo Fischer Scientific, Scotland), diluted 40x. Secondary antibodies: Donkey anti-mouse conjugated with Alexa fluor 488, diluted 1:2,000 (Life technologies, USA). Rabbit anti-goat conjugated with Alexa fluor 594, diluted 1:2,000 (Invitrogen, USA). Goat anti mouse antibody conjugated with $10 \mathrm{~nm}$ gold particles (GAM-10) (Abcam, UK) was diluted $1: 4$ in PBS/BSA.

Electron microscopy. Fixation: Cells were fixed with a mixture of $1 \%$ paraformaldehyd (Christine Gröph, Austria) and $0.5 \%$ glutaraldehyde (Applichem, Germany) in $0.2 \mathrm{~mol} / \mathrm{l}$ phosphate buffer $(\mathrm{pH}$ 7.2) at $4^{\circ} \mathrm{C}$ overnight. All the following steps were done at room temperature. The fixed cells were washed with PBS with glycine $(50 \mathrm{mg} / \mathrm{ml}$ ) for $30 \mathrm{~min}$ and then by PBS with $0.2 \%$ BSA for $30 \mathrm{~min}$.

Labeling procedures: The fixed cells were incubated with the monoclonal antibody M87 diluted 1:1 with PBS/BSA for $30 \mathrm{~min}$ and washed 3 times for $10 \mathrm{~min}$ with PBS/BSA. Incubation with GAM-10 diluted 1:4 in PBS/BSA was done for $30 \mathrm{~min}$ followed by 5 min washing with PBS/BSA, then 3 times for 15 min with PBS and finally 3 times for $5 \mathrm{~min}$ with distilled water. Staining was done with $20 \%$ uranyl acetate in distilled water for $20 \mathrm{~min}$.

Embedding and staining: After the labelling, cells were dehydrated in a graded series of acetone (30, 50, 70, 90, 100\% twice: 5 min each step), transferred into a mixture of the embedding resin LR White (Polysciences Inc., USA) and acetone (100 \%) (v/v 1:1) for $30 \mathrm{~min}$, followed by an incubation with pure resin for another $30 \mathrm{~min}$. The cells were than scraped from the glass with a razor blade into an eppendorf tube filled with resin and centrifuged for 5-10 min. The sealed capsules were polymerized for $48 \mathrm{~h}$ at $75^{\circ} \mathrm{C}$. Ultra thin sections were cut with a diamond knife, floated on water and mounted on gold grids without any supporting film. Ultra-thin sections were prepared on a LKB Ultratome ultramicrotome (LKB, Austria). The samples were examined under a Philips EM 300 electron microscope at $80 \mathrm{kV}$ (Philips, Netherlands).

Immunofluorescence. The cells were seeded on a cover slip and maintained until the next day in DMEM media with $10 \%$ fetal calf serum. Cells were fixed in 2\% paraformaldehyde (Christine Gröph) at RT for $20 \mathrm{~min}$, washed 3 times with PBS and incubated with $3 \%$ bovine serum albumin (BSA, Applichem) in PBS for $1 \mathrm{~h}$. The primary antibody was added in appropriate dilution in PBS with $0.02 \%$ Tween 20 (Sigma-Aldrich, USA) for $1 \mathrm{~h}$ at $37^{\circ} \mathrm{C}$. Cover slips were washed in PBS with $0.02 \%$ Tween 20 for 10 min 3 times at RT and secondary antibody was added. In case of double staining, the second primary antibody was added in appropriate dilution in PBS 

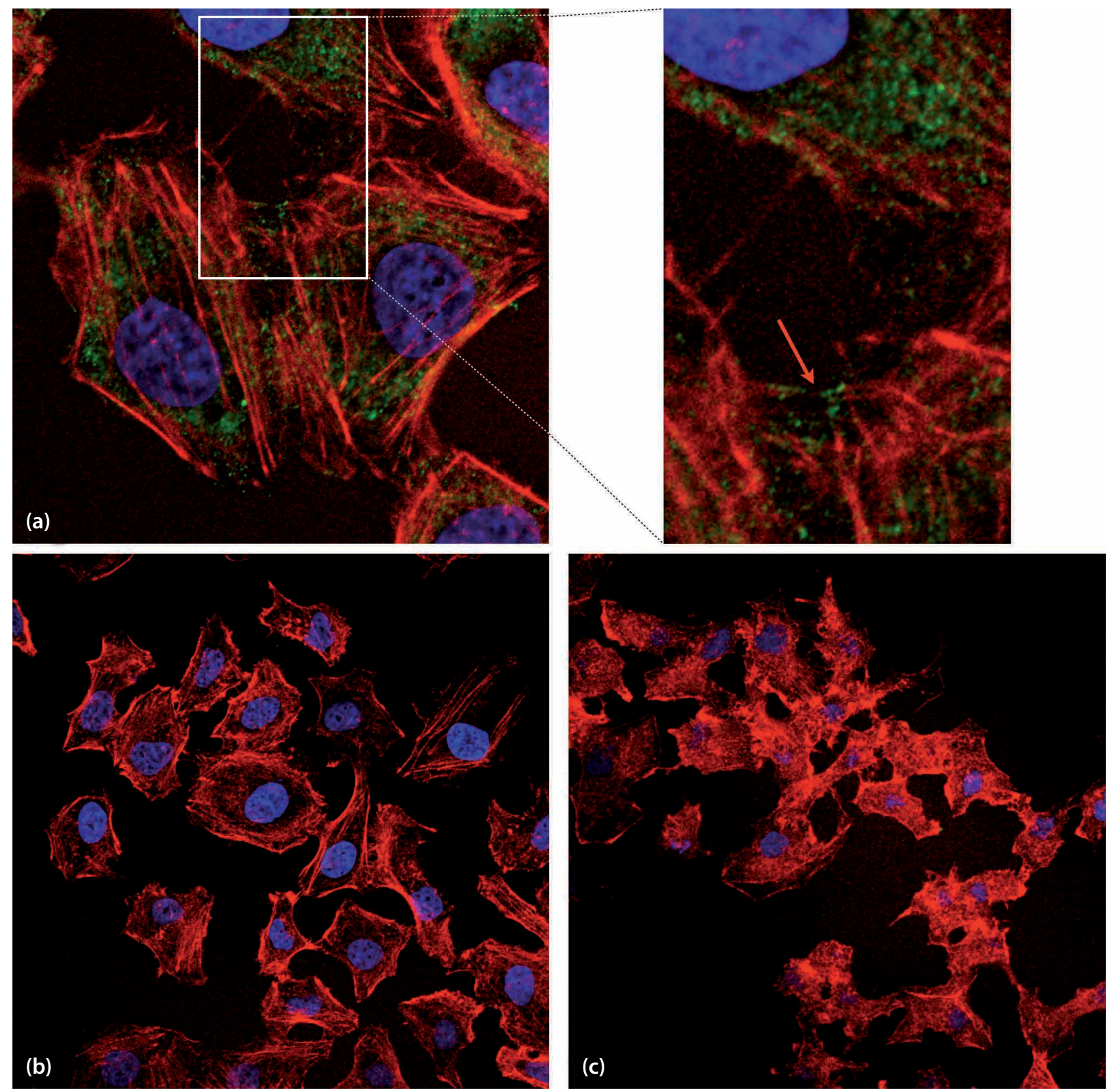

Fig. 1

Actin network

Imunofluorescence of infected HeLa/MX (a, b) with a zoom of the region with NP present on the actin filaments and uninfected HeLa cells (c). Actin network was stained with Phalloidin-AF594 (red) and viral nucleoprotein (green) with M87 antibody. Zeiss confocal microscope, magnification 630x.

with $0.02 \%$ Tween 20 for $1 \mathrm{~h}$ at $37^{\circ} \mathrm{C}$, then the cells were washed and both secondary antibodies were added. Incubation of secondary antibody was done at $37^{\circ} \mathrm{C}$ for $1 \mathrm{~h}$. The cells were washed 3 times in PBS with $0.02 \%$ Tween 20 for 10 min 3 times at RT. The DAPI (4', 6'-diamidino-2-phenylindole; Sigma-Aldrich) staining for nuclei was done at RT for $5 \mathrm{~min}$. Cells were washed, mounted on slide and analyzed under confocal microscope. Zeiss LSM510 laser scanning confocal microscopy system mounted on a Zeiss Axiovert 200M inverted microscope (Zeiss, Germany) was used. Images were taken with Plan Apochromat 63x/1.4 oil objective and scanned at scan speed 6, $1024 \times 1024$ pixels, 12-bit data depth with average mode $8 \mathrm{x}$ line. For the immunofluorescence of the live cells, the fixation 

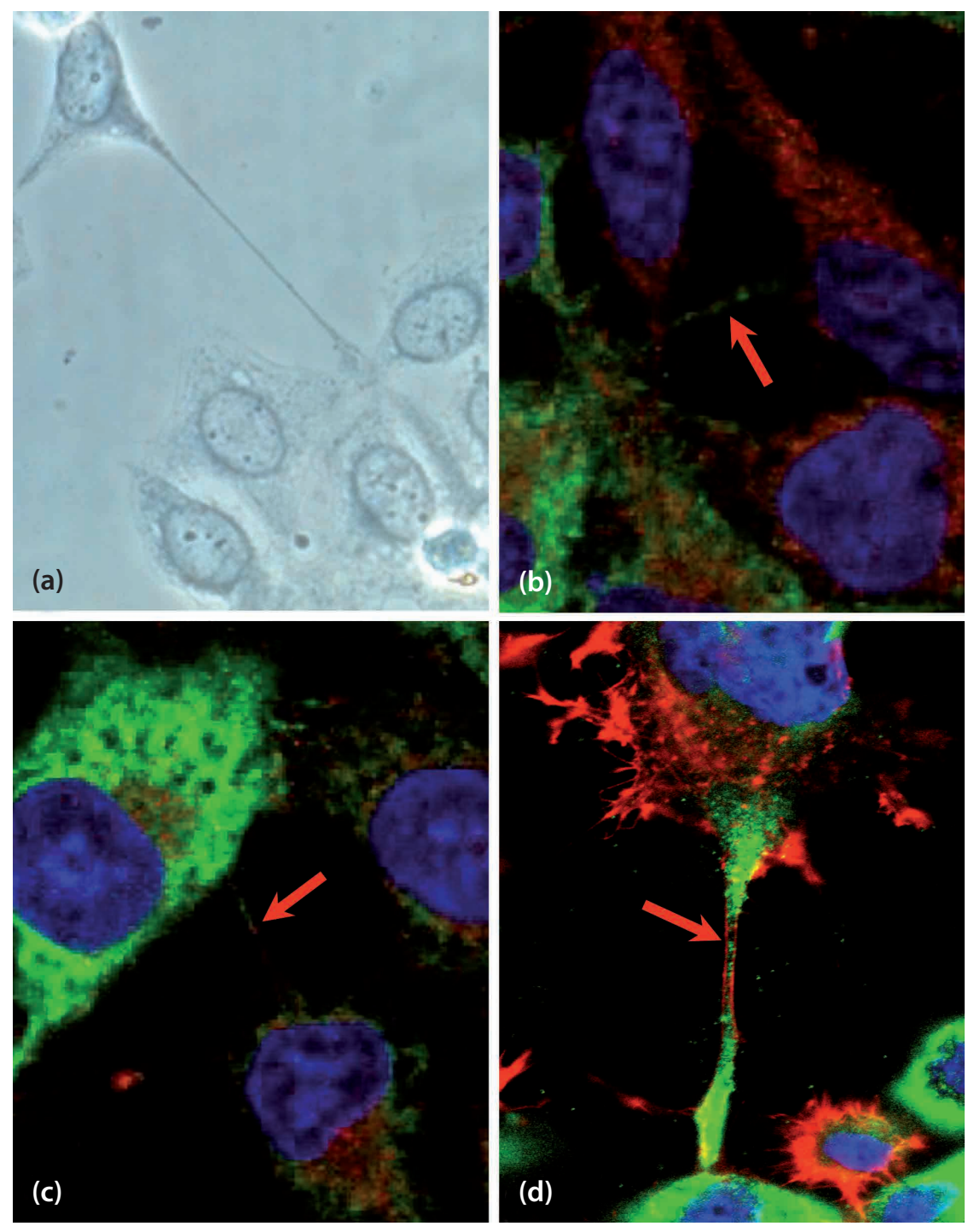

Fig. 2

Tunneling nanotubes

Light microscopy (a) and double staining immunofluorescence of infected HeLa/MX (b, c, d). Keratin 1 is stained with anti-K1 antibody (red) and viral NP is stained with anti-NP antibody M87 (green) (b, c). Actin is stained with Phaloidin-AF594 (red) and viral NP is stained with anti-NP antibody M87 (green) (d). Zeiss confocal microscope, magnification 630x.

and blocking steps were omitted. Cells grown on cover slips were washed with PBS and then incubated with M87 antibody for $1 \mathrm{~h}$ at $37^{\circ} \mathrm{C}$. The remaining steps were as stated previously, but the cells were washed only with PBS. Cells were analyzed under microscope as live cells, only in PBS without fixation. Phalloidin staining was done after the primary antibody incubation and washing. Phalloidin was added for 20 min at RT and washed 3 times.

Cell migration and wound healing assay. The cells were seeded at a concentration of $5 \times 10^{5}$ cells per $6 \mathrm{~cm}$ diameter tissue culture dish and cultivated in DMEM with $2 \%$ FCS. On the next day, the medium was changed, and 10\% FCS was added into DMEM. After
$6 \mathrm{~h}$, the cells were fixed with $2 \%$ paraformaldehyde for $20 \mathrm{~min}$ at $\mathrm{RT}$ and immunofluorescence staining for $\mathrm{K} 1$ and NP was done as stated previously. For wound healing assay, the cells were seeded at the concentration of 1 million cells per $6 \mathrm{~cm}$ diameter tissue culture dish and cultivated in DMEM with $2 \%$ FCS. On the next day, when the cells were in a confluent monolayer, the scratch with pipette tip was done and $10 \%$ FCS was added into DMEM. The cells were analyzed under the light inverted microscope Axiovert $40 \mathrm{CFL}$ (Zeiss) after 0, 2, 4 and $17 \mathrm{~h}$. Wound healing assay was analyzed in AxioVision software (Zeiss) and the percentage of the uncovered area was determined. 


\section{Results}

\section{Viral nucleoprotein associates with actin filaments}

We found that the actin network is more prominent and richer in the infected cells than in the non-infected ones (Fig. 1b,c). In the infected cells, actin forms prominent cablelike structures of mature actin. Uninfected cells form actin cables in the lower extent, however more of the indistinct aggregates can be seen. Viral NP is present at the ends of the actin filaments and at the plasma membrane where the cells are in close proximity (Fig. 1a, a zoom).

\section{Viral nucleoprotein is present in tunneling nanotubes}

By immunofluorescence we have showed that the infected cells have numerous different tubular protrusions on their surface (Fig. 2), what was also already proved in earlier work by scanning microscopy (Zavada et al., 1993). Viral NP and $\mathrm{K} 1$ were as well present in these structures connecting the cells even at longer distances (Fig. 2b,c). NP can travel inside these cellular protrusions along $\mathrm{K} 1$ even for long distances to the other cells. The presence of F-actin after Phalloidin staining, proves that those structures, inside which NP travels, are tunneling nanotubes (Fig. 2d).

\section{The presence of viral nucleoprotein on the cell surface}

Electron microscopy (Fig. 3a) shows that the virus, or at least viral NP, is present on the cell surface. The presence of NP was visibly prominent on the cell membrane of live cells where the two cells were in very close contact and where the desmosomes are present (Fig. 3b,c,e). On the cross-section of the immunofluorescence of live infected cells from confocal microscope, it can be clearly seen that the viral NP resides on the cell membrane (Fig. 3e). Nucleoprotein of MX LCMV was also present on the membrane of cellular protrusions (Fig. 3a), suggesting the possibility for the transmission to the neighboring cell by transport on the cellular protrusions surface.

\section{Faster migration of infected cells}

After culturing the cells in sparse conditions and starving in $2 \%$ FCS, we performed double staining for viral NP and $\mathrm{K} 1$. We have observed a strong formation of lamellipodia in cells infected by LCMV strain MX, while the formation of lamellipodia in uninfected cells was very poor. We also found a strong fluorescence of $\mathrm{K} 1$ in the region of leading edge of the infected cells (Fig. 4a). It is evident by fluorescence that infected cells form more lamellipodia (Fig. 4b,c) than the uninfected control cells (Fig. 4d).
Using the wound healing assay, we have shown that the LCMV infected cells migrate faster than the uninfected ones. Moreover, the cells infected with the LCMV MX strain causing persistent infection migrate even faster than the cells infected by the strain ARM causing acute infection (Fig. 5).

\section{Discussion}

The main concern of the virus is to keep its population at a certain level and disseminate effectively in the organism. Different viruses utilize different strategies for its spread with a various effectiveness.

LCMV strain MX, used in this study, is a persistent strain strongly associated with the cell. It was identified in the mammary tumor cells MaTu and later transferred to HeLa cells (Pastorekova et al., 1992; Reiserová et al., 1999; Labudova et al., 2006). MX-infected cells contain high cytoplasmatic level of NP and ZP and also full-length and deleted viral RNAs (Gibadulinova et al., 1998; Reiserová et al., 1999; Tomaskova et al., 2008). Infected cells also show the expression of GPC and only very low level of GP1 (Tomaskova et al., 2011). In previous work, it was proved by unsuccessful infection with filtered medium from infected cells, that the infected cells don't produce infectious virions (Tomaskova et al., 2011), however, the infection was successful when using the extract from the infected cells, assuming that the virus spreads by cell-to-cell transmission only. However, after the cultivation in hypoxia, the GP1 expression is induced and infectious virions are released (Tomaskova et al., 2011).

LCMV infection of the cell usually begins after the interaction of GP1 with its receptor alpha-dystroglycan, expressed on most cells (Cao et al., 1998). After the interaction with the receptor, the virus enters the cytoplasm and begins to replicate. For establishment of this type of infection, a large quantity of the virus needs to be produced, the virion needs to be stable to survive in the environment through which it travels, it needs to find the appropriate receptor and escape the immune system. Some viruses use a more effective way of transmission - transmission through cell-to-cell contacts. This mode of transmission has several advantages. Firstly, it is fast, since the virus travels inside the cellular protrusions or through the intracellular space and the virus doesn't need to look for the receptor. Secondly, it is effective, because there are no losses en route to the receptor, since the virus travels inside the cell or through the intracellular space, where there is no influence of the unfavorable environment. Thirdly, if the virus uses a receptor, the virus is released only into the extracellular space, where the receptor is in close proximity. Fourthly, virus is protected from the virus neutralization antibodies or the immune system (Zhong et al., 2013).

There are many ways of transmission by cell-to-cell contacts used by different viruses. From cell-free dissemination 

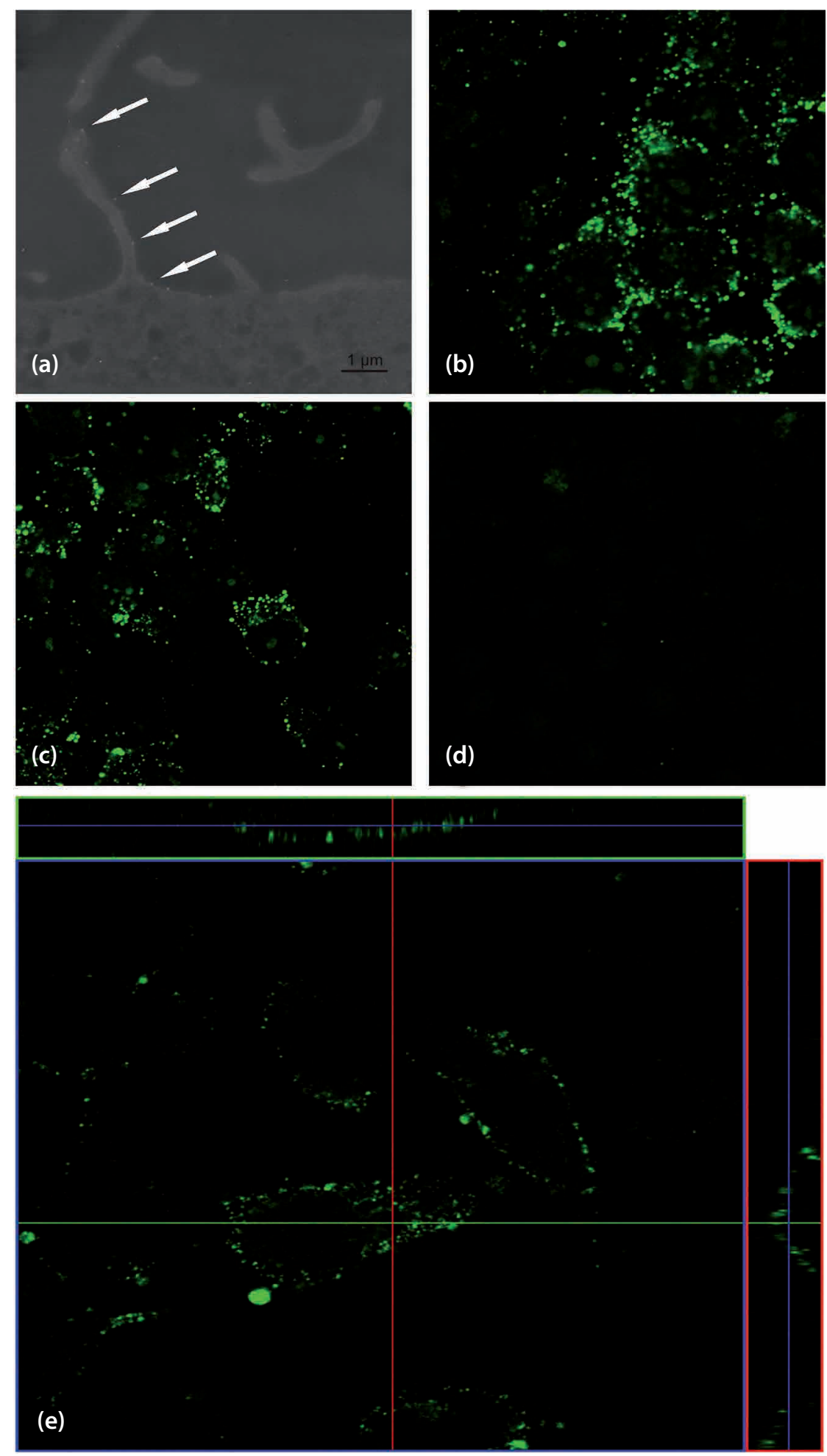

Fig. 3

Presence of virions on the membrane surface

Electron microscopy of viral NP in HeLa/MX (a). Primary NP-specific antibody was used in combination with goat anti mouse Ig-Au (10 nm) secondary antibody. Labeling is largely confirmed (arrows) to particles budding from the cell surface membrane. Bar represents $1 \mu$ m. Immunofluorescence of live infected cells HeLa/MX (b, c, e) stained with NP-specific antibody (M87, green) and uninfected HeLa cells (e) taken by Leica microscope, magnification 400x and Z-stack and vertical projection by Zeiss confocal microscope, magnification 630x (e). 

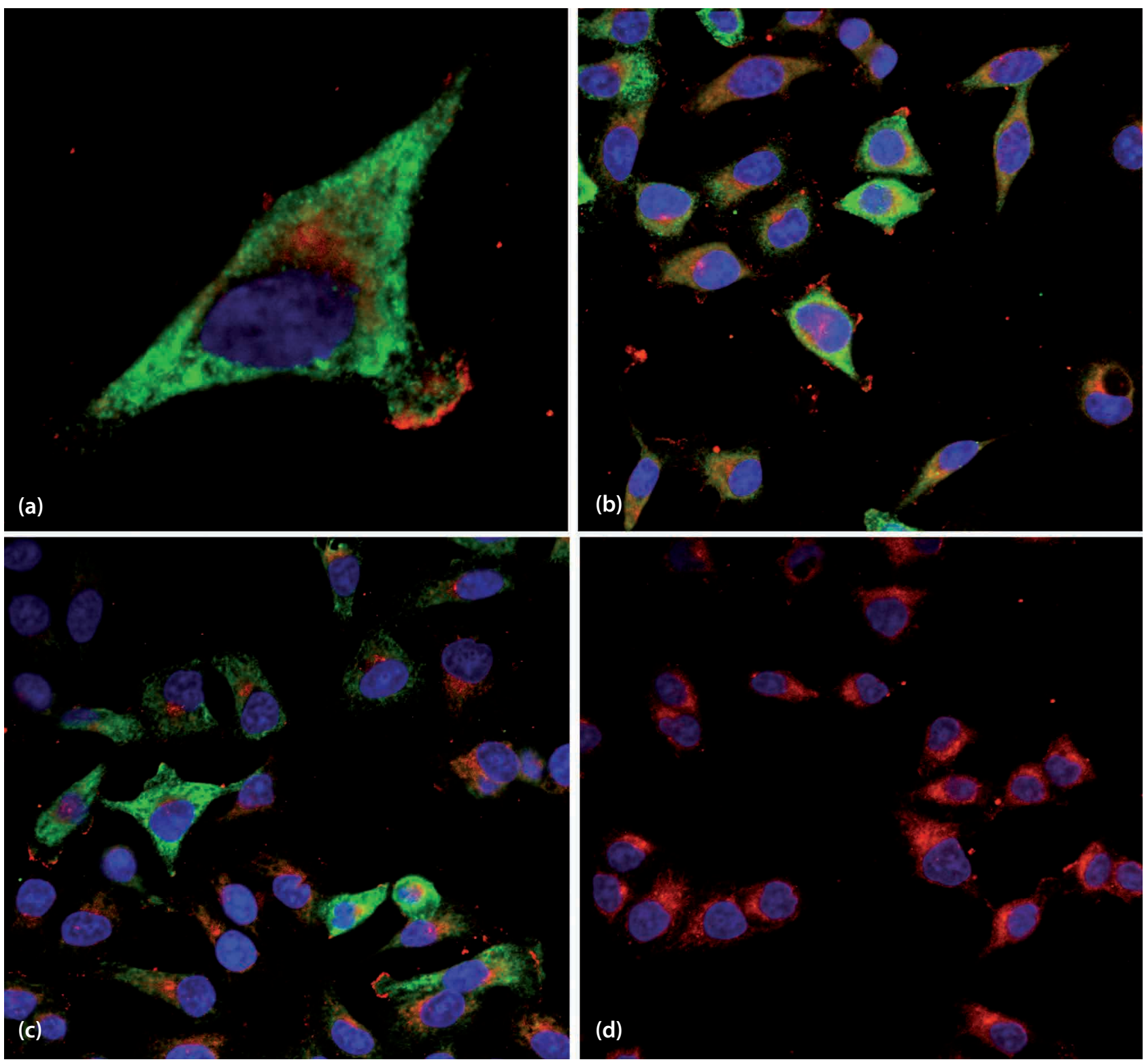

Fig. 4

Leading edge

Double staining of viral NP (green) and K1 (red), where the presence of K1 at the leading edge is clearly visible (a). Strong presence of leading edge in infected HeLa/MX cells (b, c) compared to the uninfected cells HeLa. (d) Zeiss confocal microscope, magnification 630x.

through the extracellular space at sites of cell-cell contact, virological synapses, immunological synapses to various ways of using inter-cellular membrane bridges (Zhong et al., 2013).

The vaccinia virus (VV) belongs to the family Poxviridae and causes epithelial lesions (Fenner, 1996). The viruses of this family are characteristic for rapid cell-to-cell spread in the epidermis and endothelium and they replicate and spread extremely rapidly (Johnson and Huber, 2002). VV uses microtubules, along which the intracellular mature or enveloped virus travels (Sanderson et al., 2000) to the trans Golgi network (Hiller and Weber, 1985; Schmelz et al., 1994) or tubular endosomes (Tooze et al., 1993). Virions move to the cell surface, where they are coupled to the cytoplasmatic actin tails that produce microvilli extending from the cell surface and projecting virions toward adjacent cell (Johnson and Huber, 2002). Similarly, the NP of LCMV travels to the plasmatic membrane along the K1 filaments, which was already shown previously (Labudova et al., 2009). We found 


\begin{tabular}{|l|c|c|}
\hline Cell line, time (hr) & Area of ROI & \% \\
\hline HeLa, 0 hr & 551818 & 100 \\
\hline HeLa, 2 hr & 533945 & 96,8 \\
\hline HeLa, 4 hr & 458490 & 83,1 \\
\hline HeLa, 17 hr & 238992 & 43,3 \\
\hline HeLaMX, 0 hr & 553902 & 100 \\
\hline HeLaMX, 2 hr & 291422 & 52,6 \\
\hline HeLaMX, 4 hr & 243507 & 44,0 \\
\hline HeLaMX, 17 hr & 0 & 0,0 \\
\hline HeLaARM, 0 hr & 557652 & 100 \\
\hline HeLaARM, 2 hr & 527691 & 94,6 \\
\hline HeLaARM, 4 hr & 441835 & 79,2 \\
\hline HeLaARM, 17 hr & 99550 & 17,9 \\
\hline
\end{tabular}

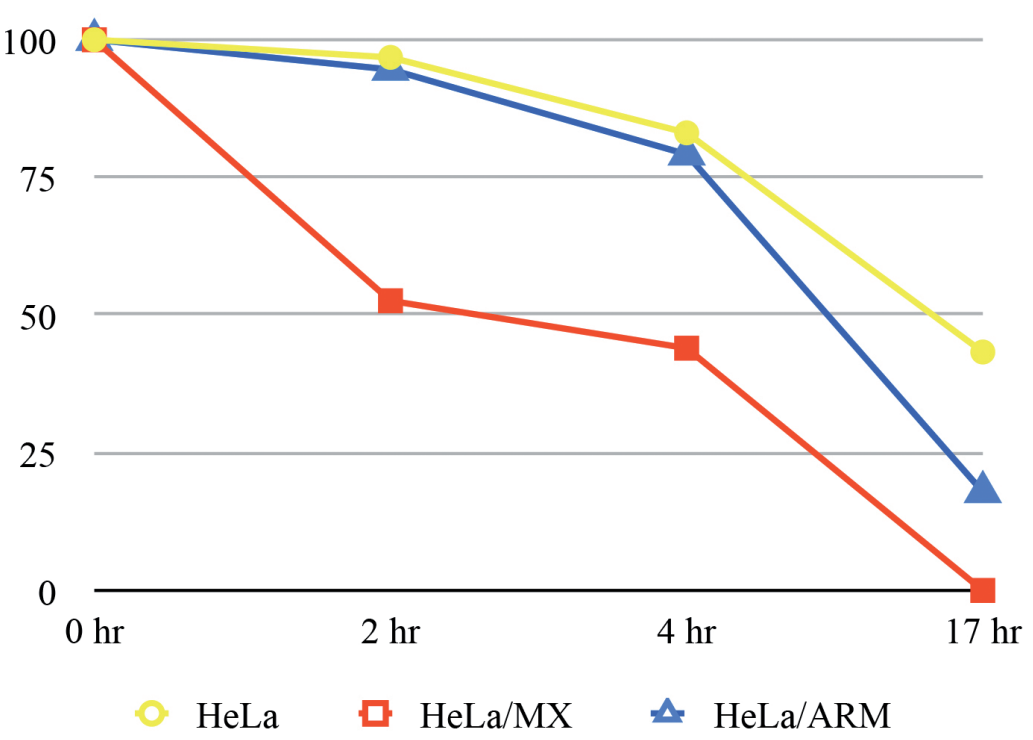

Fig. 5

Wound healing

The speed of migration of infected HeLa/MX cells, HeLa/ARM and uninfected HeLa cells. Graph represents the percentage of uncovered area after 2, 4 and $17 \mathrm{~h}$.

more prominent and richer actin network in the infected cells and viral NP associated with the ends of actin filaments. This arrangement can point to the fact that the actin network may be involved in the transmission of the virus similarly as in the case of the vaccinia virus. The viral NP would use K1 to travel to the membrane, as vaccinia uses the microtubules and then it would be propelled by actin to the neighboring cell. Thanks to rapid replication and this type of spread, vaccinia virus and also other poxviruses have very rapid cell-to-cell spread, outstripping host immune responses (Johnson and Huber, 2002). In consistence with this, it was proved that LCMV can spread extremely fast in the gastric mucosa (Yin et al., 1998) or epithelial airway (Dylla et al., 2008).

Another possible way of transmission is transport through the so called "tunneling nanotubes" (TNT). TNT form a thin membrane channels between mammalian cells (Rustom et al., 2004), which mediate membrane continuity between connected cells and allow direct intercellular transfer of diverse components (Gerdes and Rustom, 2006). TNTs are able to allow communication between dislodged cells at longer distances (Gerdes et al., 2007). Nanotubes have the ability of directed growth towards the target cell (Rustom et al., 2004) and after encounter with the target cell, both membranes fuse to form a connection (Gerdes et al., 2007). The transport along the TNTs is driven by F-actin (Gerdes et al., 2007) and in some types of nanotubes also by microtubules (Onfelt et al., 2006). Apart from the transfer of small organelles, subsequent studies showed that TNTs also facilitate the intercellular transfer of larger organelles such as mitochondria (Koyanagi et al., 2005), membrane constituents and soluble molecules (Gerdes et al., 2007). Several lines of experimental evidence suggest that nanotubes fulfil important tasks in the immune system by propagating calcium fluxes between dendritic cells (Watkins and Salter, 2005), as well as during cancer development and progression, where they seem to facilitate the intercellular shuttling of ABC transporters mediating multidrug resistances (Levchenko et al., 2005). Also, they are misused for the spread of diverse pathogens, such as prion-proteins (Magalhaes et al., 2005) or viral components (Sherer and Mothes, 2008; Sowinski et al., 2008; Eugenin et al., 2009). Viruses such as murine leukemia virus or HIV-1 induce and exploit these protrusions to travel from cell-to-cell (Eugenin et al., 2009). As the immunofluorescence shows, NP was found to be located in the tunneling nanotubes connecting two distant cells.

Another way of transmission is transmission from cell-tocell along the surface of the cellular protrusions - cytonemes. Cytonemes are non-tubular bridges, with two membranes that are tightly juxtaposed at the site of cell-cell contact and the signal must be transduced using molecules resident at the outer surface of the membrane (Sherer and Mothes, 2008). Cytonemes or filopodial bridges do not connect cytoplasm of two cells, but still enable the transport of ligands across the outer surface (Sherer and Mothes, 2008).

In HIV-1 infection, after budding, viruses "surf" directionally along the outer surface of the linkage toward the 
uninfected target cell before fusion and entry at the cell body (Sherer and Mothes, 2008). Surfing is driven by retrograde F-actin flow, a myosin II-driven process occurring constitutively in filopodium that delivers bound substrates inward toward the cell center (Gut et al., 2002).

As proved by immunofluorescence on live cells (Labudova et al., 2009) and now also by electron microscopy the virus or at least viral NP is present on the cell surface. Nucleoprotein presence on the membrane of cellular protrusions suggests a possible mode of transmission to the cells on longer distances by transport on the cellular protrusions surface. Viral NP present on the membrane and during transport (in all forms of transmission) is in the form of ribonucleoprotein, the minimal infectious unit, which consists of NP, viral polymerase and RNA.

Cell migration requires continuous forward movement of the plasma membrane at the cell's front or "leading edge". Four distinct ways of extending the membrane at the leading edge have been described so far. In lamellipodia and filopodia, actin polymerization directly pushes the plasma membrane forward, whereas in invadopodia, actin couples with extracellular delivery of matrix-degrading enzymes to clear the path through the extracellular matrix. Membrane blebs drive the plasma membrane forward using actomyosin and cortical actin cytoskeleton (Ridley, 2011). Keratin-filament (KF) network precursor formation occurs preferentially in lamellipodia of migrating cells. Previously, after scratch wounding, abundant keratin filament precursors (KFPs) were seen at the leading edge of approaching cells, thereby extending the intermediate filament cytoskeleton towards the gap. This was also seen in single migrating cells (Kolsch et al., 2010). Great majority of lamellipodial KFPs are located at the distal tips of actin stress fibers until their integration into the peripheral KF network (Windoffer et al., 2004, 2006; Woll et al., 2005). Overall, abundant KFP formation was noted in lamellipodia containing abundant actin anchoring focal adhesions (FAs) and KFP were only seen after the establishment of FAs in emerging lamellipodia. KFPs appear remarkably close to FAs. FAs may have a regulatory function for KF assembly, thereby providing the basis for coordinated shaping of the entire cytoskeleton during cell relocation and rearrangement (Windoffer et al., 2006).

In this work we have showed that the infected cells produce more lamellipodia associated with stronger expression of keratin 1. The MX strain of LCMV may induce the formation of keratin network and induce the speed of cellular rearrangement and migration. We have also showed faster migration of infected cells, with MX-infected cells migrating even faster than those infected with other LCMV strains. The infectious virions of ARM strain of LCMV are released from the cell and the infection is established by virion-receptor interaction, so the migration is not necessary for effective infection of this strain.
The presence of the virus forces the cell to migrate faster and extensively to the nearest cell to establish further dissemination of the virus. It is possible that the virus could stabilize or maybe induce the expression of $\mathrm{K} 1$ and its formation into intermediate filaments and allowing efficient migration, maintaining thus its own fast dissemination through the cell-to-cell contacts.

In this work, we have presented several routes that the virus could utilize in its spread in cell culture or also in the organism. LCMV employs a very effective and fast way of dissemination by cell-to-cell contacts and according to our results, we can assume that it takes advantage of more possibilities of such transmission. These three and maybe also some other ways of transmission are not separated, and they work together and may alter each other when one or more is missing. Moreover, the virus is not only using the cell-to-cell contacts for spread, but it is also able to stimulate the cell to faster remodeling of the cytoskeletal network as well as migration to ensure its faster spread.

These findings show that the virus uses more than one of the transmission systems and all have a common feature, actin and K1. From cytoskeletal network components, K1 could be used as a target for antiviral therapy, since its presence is not essential for the cell. Another possibility could be dynamin, regulator of cytoskeleton dynamics, including actin. It was already proved that inhibition of dynamin can slow down or stop the transport of viral proteins (Raux et al., 2010; Mues et al., 2015;). Inhibition of dynamins could hinder all three cell-to-cell spread ways that LCMV strain MX uses. Also, it could hinder the migration of infected cells, since dynamins participate in the formation of actinrich structures, including lamellipodia (Ferguson and De Camilli, 2012).

A detailed knowledge of viral transmission is important for the future perspectives of antiviral therapy, especially in case of persistent infection.

Acknowledgments. Strain Armstrong (ARM) was obtained from Dr. Boris Klempa, PhD (Institute of Virology, BMC SAS, Bratislava, Slovakia). This work was supported by VEGA-2/0146/12 grant from the Scientific Grant Agency of Ministry of Education of the Slovak Republic.

\section{References}

Barry A, Gunn J, Tormey P, McCarthy T, Pendarvis J, Delmonico F, Sussman L, Fitzpatrick S, Gautam A, Sulis C, Wong M, Pillai S, Arya M, Stillman I, Wright SB, Karp S, Goodell P, DeMaria A, Brown C, Cumming M, Matyas B, Hull M, Schillie S (2008): Brief Report: Lymphocytic Choriomeningitis Virus Transmitted Through Solid Organ Transplantation - Massachusetts, 2008. MMWR 57, 799-801. 
Buchmeier MJ, Welsh RM, Dutko FJ, Oldstone MB (1980): The virology and immunobiology of lymphocytic choriomeningitis virus infection. Adv. Immunol. 30, 275-331. https://doi.org/10.1016/S0065-2776(08)60197-2

Cao W, Henry MD, Borrow P, Yamada H, Elder JH, Ravkov EV, Nichol ST, Compans RW, Campbell KP, Oldstone MB (1998): Identification of alpha-dystroglycan as a receptor for lymphocytic choriomeningitis virus and Lassa fever virus. Science 282, 2079-2081. https://doi.org/10.1126/ science.282.5396.2079

Dylla DE, Michele DE, Campbell KP, McCray PB, Jr. (2008): Basolateral entry and release of New and Old World arenaviruses from human airway epithelia. J. Virol. 82, 6034-6038. https://doi.org/10.1128/JVI.00100-08

Eugenin EA, Gaskill PJ, Berman JW (2009): Tunneling nanotubes (TNT) are induced by HIV-infection of macrophages: a potential mechanism for intercellular HIV trafficking. Cell Immunol. 254, 142-148. https://doi.org/10.1016/j. cellimm.2008.08.005

Fenner F (1996): Poxviruses. In Fields BN, Knipe, DM, Howley PM (Eds): Fields Virology. Lippincot-Raven, Philadeplhia, pp. 2673-2702.

Ferguson SM, De Camilli P (2012): Dynamin, a membraneremodelling GTPase. Nat. Rev. Mol. Cell Biol. 13, 75-88. https://doi.org/10.1038/nrm3266

Fischer SA, Graham MB, Kuehnert MJ, Kotton CN, Srinivasan A, Marty FM, Comer JA, Guarner J, Paddock CD, DeMeo DL, Shieh WJ, Erickson BR, Bandy U, DeMaria A, Jr., Davis JP, Delmonico FL, Pavlin B, Likos A, Vincent MJ, Sealy TK, Goldsmith CS, Jernigan DB, Rollin PE, Packard MM, Patel M, Rowland C, Helfand RF, Nichol ST, Fishman JA, Ksiazek T, Zaki SR, Team LiTRI (2006): Transmission of lymphocytic choriomeningitis virus by organ transplantation. N. Engl. J. Med. 354, 2235-2249. https://doi.org/10.1056/NEJMoa053240

Gerdes HH, Bukoreshtliev NV, Barroso JF (2007): Tunneling nanotubes: a new route for the exchange of components between animal cells. FEBS Lett. 581, 2194-2201. https:// doi.org/10.1016/j.febslet.2007.03.071

Gerdes HH, Rustom A (2006): Tunneling nanotubes: membranous channels between animal cells. In Baluška, F, Volkmann D, Barlow PW (Eds): Cell-cell Channels, Landes Bioscience/Springer Science + Business Media, Georgtown / New York, pp. 200-207.

Gibadulinova A, Zelnik V, Reiserova L, Zavodska E, Zatovicova M, Ciampor F, Pastorekova S, Pastorek J (1998): Sequence and characterisation of the $\mathrm{Z}$ gene encoding ring finger protein of the lymphocytic choriomeningitis virus MX strain. Acta Virol. 42, 369-374.

Gut MO, Parkkila S, Vernerova Z, Rohde E, Zavada J, Hocker M, Pastorek J, Karttunen T, Gibadulinova A, Zavadova Z, Knobeloch KP, Wiedenmann B, Svoboda J, Horak I, Pastorekova S (2002): Gastric hyperplasia in mice with targeted disruption of the carbonic anhydrase gene Car9. Gastroenterology 123, 1889-1903. https://doi. org/10.1053/gast.2002.37052
Hiller G, Weber K (1985): Golgi-derived membranes that contain an acylated viral polypeptide are used for vaccinia virus envelopment. J. Virol. 55, 651-659.

Jahrling PB, Peters CJ (1992): Lymphocytic choriomeningitis virus. A neglected pathogen of man. Arch. Pathol. Lab. Med. $116,486-488$.

Johnson DC, Huber MT (2002): Directed egress of animal viruses promotes cell-to-cell spread. J. Virol. 76, 1-8. https://doi. org/10.1128/JVI.76.1.1-8.2002

Kolsch A, Windoffer R, Wurflinger T, Aach T, Leube RE (2010): The keratin-filament cycle of assembly and disassembly. J. Cell Sci. 123, 2266-2272. https://doi.org/10.1242/jcs.068080

Koyanagi M, Brandes RP, Haendeler J, Zeiher AM, Dimmeler S (2005): Cell-to-cell connection of endothelial progenitor cells with cardiac myocytes by nanotubes: a novel mechanism for cell fate changes? Circ. Res. 96, 1039-1041. https://doi.org/10.1161/01.RES.0000168650.23479.0c

Labudova M, Tomaskova J, Kaluzova M, Pastorek J, Pastorekova S (2006): Lymphocytic choriomeningitis virus $m x$ strain does not induce the expression of tumor-associated carbonic anhydrase IX in persistently infected HeLa cells. Acta Virol. 50, 53-58.

Labudova M, Tomaskova J, Skultety L, Pastorek J, Pastorekova S (2009): The nucleoprotein of lymphocytic choriomeningitis virus facilitates spread of persistent infection through stabilization of the keratin network. J. Virol. 83, 7842-7849. https://doi.org/10.1128/JVI.00309-09

Levchenko A, Mehta BM, Niu X, Kang G, Villafania L, Way D, Polycarpe D, Sadelain M, Larson SM (2005): Intercellular transfer of P-glycoprotein mediates acquired multidrug resistance in tumor cells. Proc. Natl. Acad. Sci. USA 102, 1933-1938. https://doi.org/10.1073/pnas.0401851102

Magalhaes AC, Baron GS, Lee KS, Steele-Mortimer O, Dorward D, Prado MA, Caughey B (2005): Uptake and neuritic transport of scrapie prion protein coincident with infection of neuronal cells. J. Neurosci. 25, 5207-5216. https:// doi.org/10.1523/JNEUROSCI.0653-05.2005

Meyer BJ, Southern PJ (1997): A novel type of defective viral genome suggests a unique strategy to establish and maintain persistent lymphocytic choriomeningitis virus infections. J. Virol. 71, 6757-6764.

MMWR-Dispatch (2005): Lymphocytic Choriomeningitis Virus Infection in Organ Transplant Recipients - Massachusetts, Rhode Island, 2005. MMWR 54, 537-539.

Mues MB, Cheshenko N, Wilson DW, Gunther-Cummins L, Herold BC (2015): Dynasore disrupts trafficking of herpes simplex virus proteins. J. Virol. 89, 6673-6684. https:// doi.org/10.1128/JVI.00636-15

Onfelt B, Nedvetzki S, Benninger RK, Purbhoo MA, Sowinski S, Hume AN, Seabra MC, Neil MA, French PM, Davis DM (2006): Structurally distinct membrane nanotubes between human macrophages support long-distance vesicular traffic or surfing of bacteria. J. Immunol. 177, 84768483. https://doi.org/10.4049/jimmunol.177.12.8476

Pastorekova S, Zavadova Z, Kostal M, Babusikova O, Zavada J (1992): A novel quasi-viral agent, MaTu, is a twocomponent system. Virology 187, 620-626. https://doi. org/10.1016/0042-6822(92)90464-Z 
Peters CJ, Buchmeier MJ, Rollin PE, Ksiazek TG (1996): Arenaviruses. Lippincott-Raven Publishers. Philadelphia.

Popescu M, Schaefer H, Lehmann-Grube F (1976): Homologous interference of lymphocytic choriomeningitis virus: detection and measurement of interference focus-forming units. J. Virol. 20, 1-8.

Raux H, Obiang L, Richard N, Harper F, Blondel D, Gaudin Y (2010): The matrix protein of vesicular stomatitis virus binds dynamin for efficient viral assembly. J. Virol. 84, 12609-12618. https://doi.org/10.1128/JVI.01400-10

Reiserová L, Kaluzová M, Kaluz S, Willis AC, Závada J, Závodská E, Závadová Z, Ciampor F, Pastorek J, Pastoreková S (1999): Identification of MaTu-MX agent as a new strain of lymphocytic choriomeningitis virus (LCMV) and serological indication of horizontal spread of LCMV in human population. Virology 257, 73-83. https://doi. org/10.1006/viro.1999.9638

Ridley AJ (2011): Life at the leading edge. Cell 145, 1012-1022. https://doi.org/10.1016/j.cell.2011.06.010

Rustom A, Saffrich R, Markovic I, Walther P, Gerdes HH (2004): Nanotubular highways for intercellular organelle transport. Science 303, 1007-1010. https://doi.org/10.1126/ science. 1093133

Salvato MS, Shimomaye EM (1989): The completed sequence of lymphocytic choriomeningitis virus reveals a unique RNA structure and a gene for a zinc finger protein. Virology 173, 1-10. https://doi.org/10.1016/0042-6822(89)90216$\underline{\mathrm{X}}$

Sanderson CM, Hollinshead M, Smith GL (2000): The vaccinia virus A27L protein is needed for the microtubule-dependent transport of intracellular mature virus particles. J. Gen. Virol. 81, 47-58. https://doi.org/10.1099/0022-1317$\underline{81-1-47}$

Schmelz M, Sodeik B, Ericsson M, Wolffe EJ, Shida H, Hiller G, Griffiths G (1994): Assembly of vaccinia virus: the second wrapping cisterna is derived from the trans Golgi network. J. Virol. 68, 130-47.

Sherer NM, Mothes W (2008): Cytonemes and tunneling nanotubules in cell-cell communication and viral pathogenesis. Trends Cell Biol. 18, 414-420. https://doi.org/10.1016/j. $\underline{\text { tcb.2008.07.003 }}$

Southern PJ (1996): Arenaviridae: The viruses and their replication. Fields Virology, Lippincot-Raven Publishers, Philadelphia, pp. 1505-1519.

Southern PJ, Singh MK, Riviere Y, Jacoby DR, Buchmeier MJ, Oldstone MB (1987): Molecular characterization of the genomic S RNA segment from lymphocytic choriomeningitis virus. Virology 157, 145-155. https://doi. org/10.1016/0042-6822(87)90323-0

Sowinski S, Jolly C, Berninghausen O, Purbhoo MA, Chauveau A, Kohler K, Oddos S, Eissmann P, Brodsky FM, Hopkins C, Onfelt B, Sattentau Q, Davis DM (2008): Membrane nanotubes physically connect $\mathrm{T}$ cells over long distances presenting a novel route for HIV-1 transmission. Nat. Cell Biol. 10, 211-219. https://doi.org/10.1038/ncb1682

Tomaskova J, Labudova M, Kopacek J, Pastorekova S, Pastorek J (2008): Molecular characterization of the genes coding for glycoprotein and L protein of lymphocytic choriomeningitis virus strain MX. Virus Genes 37, 31-38. https://doi. org/10.1007/s11262-008-0240-2

Tomaskova J, Oveckova I, Labudova M, Lukacikova L, Laposova K, Kopacek J, Pastorekova S, Pastorek J (2011): Hypoxia induces the gene expression and extracellular transmission of persistent lymphocytic choriomeningitis virus. J. Virol. 85, 13069-13076. https://doi.org/10.1128/JVI.00829-11

Tooze J, Hollinshead M, Reis B, Radsak K, Kern H (1993): Progeny vaccinia and human cytomegalovirus particles utilize early endosomal cisternae for their envelopes. Eur. J. Cell Biol. 60, 163-178.

van der Zeijst BA, Bleumink N, Crawford LV, Swyryd EA, Stark GR (1983): Viral proteins and RNAs in BHK cells persistently infected by lymphocytic choriomeningitis virus. J. Virol. $48,262-70$.

Watkins SC, Salter RD (2005): Functional connectivity between immune cells mediated by tunneling nanotubules. Immunity 23, 309-318. https://doi.org/10.1016/j.immuni.2005.08.009

Windoffer R, Kolsch A, Woll S, Leube RE (2006): Focal adhesions are hotspots for keratin filament precursor formation. J. Cell Biol. 173, 341-348. https://doi.org/10.1083/ jcb. 200511124

Windoffer R, Woll S, Strnad P, Leube RE (2004): Identification of novel principles of keratin filament network turnover in living cells. Mol. Biol. Cell 15, 2436-2348. https://doi. org/10.1091/mbc.e03-09-0707

Woll S, Windoffer R, Leube RE (2005): Dissection of keratin dynamics: different contributions of the actin and microtubule systems. Eur. J. Cell Biol. 84, 311-28. https://doi. org/10.1016/j.ejcb.2004.12.004

Wright KE, Spiro RC, Burns JW, Buchmeier MJ (1990): Post-translational processing of the glycoproteins of lymphocytic choriomeningitis virus. Virology 177, 175-83. https://doi. org/10.1016/0042-6822(90)90471-3

Yin C, Djavani M, Schenkel AR, Schmidt DS, Pauza CD, Salvato MS (1998): Dissemination of lymphocytic choriomeningitis virus from the gastric mucosa requires $\mathrm{G}$ protein-coupled signaling. J. Virol. 72, 8613-8619.

Zavada J, Zavadova Z, Pastorekova S, Ciampor F, Pastorek J, Zelnik V (1993): Expression of MaTu-MN protein in human tumor cultures and in clinical specimens. Int. J. Cancer 54, 268-274. https://doi.org/10.1002/ijc.2910540218

Zhong P, Agosto LM, Munro JB, Mothes W (2013): Cell-to-cell transmission of viruses. Curr. Opin. Virol. 3, 44-50. https://doi.org/10.1016/j.coviro.2012.11.004 